Khalif Muaamar \& Adibah, "Konsep Kesetaraan Gender Menurut Perspektif Islam \& Barat," Afkār Vol. 21 Issue 2 (2019): 33-74

\title{
KONSEP KESETARAAN GENDER MENURUT PERSPEKTIF ISLAM DAN BARAT ${ }^{1}$
}

\author{
THE CONCEPT OF GENDER EQUALITY IN \\ ISLAM AND THE WEST
}

Khalif Muammar A. Harris*, Adibah Muhtar**

*RZS-CASIS. Faculty of Social Science \& Humanities. Universiti Teknologi Malaysia. 54100. Kuala Lumpur.

Malaysia.

**Academy of Islamic Civilization. Faculty of Social

Science \& Humanities. Universiti Teknologi Malaysia.

54100. Kuala Lumpur. Malaysia.

Email: *khalif@utm.my

DOI: https://doi.org/10.22452/afkar.vol21 no2.2

\begin{abstract}
This article is an intellectual response to the feminists' contention that gender is a social construct, hence it can be changed and reconstructed accordingly. It argues that gender is God-given, which means that it is the natural dispositions and characters bestowed by God along with the physical appearances, which in Islamic tradition are called fitrah and sunnatullāh. By advocating the idea that gender is man-made and not God-given, the feminists have opened the door of confusion, reconstruction and corruption of not only the meaning of gender but also other fundamental concepts in the social system, such as qiwämah or men leadership. Moreover, the feminists' idea of gender equality ( $m u s \bar{a} w \bar{a} h)$ indirectly dismissed the different natural disposition (fitrah) between men and women for a notion of equality which is assumed to be synonymous with justice. Nevertheless, the
\end{abstract}

\footnotetext{
${ }^{1}$ Kajian ini merupakan output dari Fundamental Research Grant 2018, KPM-UTM (PY/2018/03814), "Pembangunan Model Pemerkasaan Wanita Malaysia Berasaskan Kerangka Konstruksi Gender (Gender Construct) Menurut Islam”.
} 
occurrence of misinterpretation in the works and practices of the conservative Pseudo-Salafi, which, among other things imposes niqāb and burqa' on women makes the advocacy and struggle of the Muslim feminists for equality between men and women seems justified and legitimate. Contrary to Western experience, Muslim societies have already been introduced to gender justice and respect for women in a manner never known before. The dissemination of feminists' ideas among Muslims is indeed loaded with colonial agenda and causes more confusion in the minds of Muslims.

Keywords: gender equality; musāwāh; qiwāmah; feminism; fițrah; Islamic tradition.

\section{Khulasah}

Artikel ini merupakan sanggahan ilmiah terhadap dakwaan golongan feminis bahawa gender adalah binaan masyarakat (social construct) yang ditentukan oleh manusia dan boleh berubah-ubah. Sebaliknya, ia menegaskan bahawa gender merupakan suatu ketentuan Tuhan, yakni sifat-sifat pembawaan dan kecenderungan semulajadi yang dikurniakan oleh Tuhan sama seperti sifat-sifat fizikal, yang di dalam agama Islam dikenali dengan fitrah dan sunnatullāh. Dengan meletakkan manusia sebagai penentu kepada gender dan bukannya Tuhan, feminisme bukan sahaja telah mencetuskan kecelaruan dalam faham gender bahkan membuka ruang kepada perombakan dan kerosakan makna terhadap konsep-konsep asasi lain dalam sistem sosial, seperti qiwämah atau kepimpinan lelaki ke atas wanita. Melalui idea kesetaraan gender (musāwāh), feminis menolak perbezaan fițrah lelaki dan perempuan demi kesamarataan yang dianggap sama dengan keadilan. Kewujudan salah tafsiran kelompok konservatif Pseudo-Salafi dalam memahami dan melaksanakan ajaran Islam berkaitan wanita menyebabkan kemunculan aktivis feminis Muslim yang memperjuangkan agenda pembebasan wanita dan kesetaraan gender secara mutlak mengikut 
acuan Barat. Hakikatnya, berbanding Barat, masyarakat Islam sejak zaman Rasulullah telah mengenal konsep keadilan gender dan penghormatan terhadap wanita yang tidak pernah diketahui sebelumnya. Justeru penyebaran idea-idea feminisme di kalangan masyarakat Islam selain membawa agenda kolonialisme juga menimbulkan lebih banyak kecelaruan pemikiran di kalangan orang Islam.

Kata kunci: kesetaraan gender; musāwāh; qiwāmah; feminisme; fitrah; tradisi Islam.

\section{Pengenalan}

Agama Islam dan Kristian bersepakat bahawa Adam adalah manusia pertama yang diciptakan Allah SWT di syurga, sebelum diturunkan ke Bumi. Bahkan kedua sumber suci Islam dan Kristian juga menyebut tentang penciptaan Hawa daripada Adam. Meskipun Bible ada menyebut bahawa Hawa (Eve) diciptakan daripada tulang rusuk, ${ }^{2}$ dan cerita yang sama ada disebutkan dalam sebuah hadith, namun para ulama' berpendapat bahawa perkataan daripada tulang rusuk (min dil) tidak harus difahami secara harfiah akan tetapi perlu difahami secara kiasan atau majāzi (metaphorical), ${ }^{3}$ iaitu bahawa wanita diciptakan seperti

\footnotetext{
2 Sila lihat Bible, Kejadian, 2:20-25, https://alkitab.sabda.org/passage.php?passage=Kej\%202:20$25 \&$ tab $=$ text.
}

${ }^{3}$ Hadith Rasulullah s.a.w yang bermaksud: "Nasihatilah para wanita dengan baik, kerana wanita diciptakan daripada tulang rusuk yang bengkok dan yang paling bengkok daripada tulang rusuk itu adalah pangkalnya, jika kamu cuba untuk meluruskannya maka ia akan patah, namun bilamana kamu biarkan ia maka ia akan tetap bengkok, untuk itu, nasihatilah para wanita dengan baik", hadith riwayat al-Bukhāri, no. 3331, Muslim Hadith no. 3632. Lihat huraian al-Nawawi dan Ibn Hajar tentang hadith ini berbeza dengan tafsiran harfiah yang dikemukakan oleh Ibn Kathīr. Al-Nawawī, Sharh Șạ̄h Muslim (Beirut: Dār al-Ma'rifah, 1998), 10:299; Ibn Hajar al-“Asqalani, Fath al-Bārī (Riyadh: Dār al-Salām, t.t.), 6:444. Untuk perbahasan lanjut tentang hadith ini sila lihat makalah penulis, "Wacana Kesetaraan Gender: Islamis versus Feminis Muslim” dalam Atas Nama 
tulang rusuk yang bengkok sehingga menuntut kebijaksanaan kaum lelaki agar hakikat wanita yang berlainan tabi'inya itu dapat ditangani dengan lemah lembut dan berhemah kerana tindakan yang kasar dan memaksa boleh menyebabkan kaum wanita patah dan tidak dapat diperbetulkan lagi.

Lebih dari itu, suatu hal yang tidak diterangkan dalam agama Kristian, al-Qur'an juga menjelaskan bahawa lelaki dan wanita diciptakan daripada satu jiwa (min nafsin wāhidah). ${ }^{4}$ Mereka umpama dua sisi dari duit syiling yang sama. Ini memberi isyarat bahawa keduanya memerlukan satu sama lain, diciptakan berpasangan, agar mereka dapat membina rumahtangga dan meninggalkan zuriat. Pemeliharaan nasab (keturunan), oleh kerana itu, menjadi objektif Syari'ah (maqāssid al-sharī'ah), sesuatu yang tidak dapat dipelihara jika perkahwinan sesama jenis dibenarkan dan dibiarkan berleluasa.

Penciptaan manusia diterangkan dengan terperinci di dalam al-Qur'an. Al-Qur'an menegaskan bahawa manusia diciptakan mengikut fitrah yang ditetapkan oleh Allah. ${ }^{5}$ Di antara fitrah manusia adalah kemampuan akliah untuk berfikir tentang Tuhan, kemampuan untuk mengetahui baik, buruk, benar dan salah, kemampuan untuk

Kebenaran: Tanggapan Kritis Terhadap Wacana Islam Liberal (Bangi: ATMA, 2009), 183.

${ }^{4}$ Dalam surah al-Nisā' ayat 1 Allah berfirman yang maksudnya: "Wahai sekalian manusia! Bertaqwalah kepada Tuhan kamu yang telah menjadikan kamu (bermula) dari diri yang satu jiwa, dan yang menjadikan daripada jiwa itu pasangannya (isterinya - Hawa), dan juga yang membiakkan dari keduanya - zuriat keturunan - lelaki dan perempuan yang ramai." Lihat juga surah al-A'rāf: 189; al-Zumar: 6.

5 "(Setelah jelas kesesatan syirik itu) maka hadapkanlah dirimu (engkau dan pengikut-pengikutmu, wahai Muhammad) ke arah ugama yang jauh dari kesesatan; (turutlah terus) fitrah (ugama) Allah, iaitu fitrah yang Allah menciptakan manusia (dengan keadaan bersedia dari semulajadinya) untuk menerimanya; tidaklah patut ada sebarang perubahan pada ciptaan Allah itu; itulah ugama yang betul lurus, tetapi kebanyakan manusia tidak mengetahui" Surah al-Rūm: 30. 
menghargai dan mencintai kebenaran, keadilan dan keindahan, sehingga tindakan manusia yang memilih tunduk dan patuh kepada perintah Allah, beribadah hanya kepadaNya, merupakan tindakan yang sesuai dengan fitrah dan hakikat dirinya, dan mencapai kebahagiaan dengannya.

Dengan fitrah istimewa yang diberikan kepada manusia, fitrah untuk mengenal dan menghambakan diri kepada Tuhan, manusia mempunyai peranan yang telah ditentukan sejak sebelum kewujudannya di muka bumi, iaitu sebagai Khalifah Allah. ${ }^{6}$ Justeru, agar manusia tahu siapa dirinya, mengapa dan untuk apa ia diciptakan Allah SWT mengutus para nabi untuk menyampaikan kebenaran daripada Tuhan Pencipta.

Bertentangan dengan falsafah eksistentialisme ${ }^{7}$ yang menegaskan bahawa 'existence precedes essence' (kewujudan mendahului esensi), kita dapat memastikan bahawa dalam Islam yang berlaku adalah sebaliknya iaitu 'essence precedes existence,' bahawa esensi manusia telah ditentukan terlebih dahulu oleh Tuhan sebelum manusia diciptakan. Ini bermakna bahawa hakikat manusia bukan ditentukan oleh manusia sendiri setelah hidup di bumi, sebagaimana dinyatakan oleh falsafah eksistensialisme, melainkan telah ditentukan oleh Allah sejak azali, sebelum diciptakannya Adam.

Penciptaan manusia dan alam ini, mengikut konsep wahdat al-wujüd, adalah suatu bentuk manifestasi kebesaran Asma dan Sifat Allah SWT. Ini kerana, orang yang mentawhidkan Allah dengan sebenar-benarnya adalah orang yang melihat bahawa yang wujud secara hakiki hanyalah Allah dan PerbuatanNya. ${ }^{8}$ Segala sesuatu telah

\footnotetext{
${ }^{6}$ Surah al-Baqarah: 30.

${ }^{7}$ Lihat sebagai contoh Jean-Paul Sartre, Existentialism and Humanism, terjemahan dan pengenalan oleh Philip Mairet (London: Methuen, 1948), 28.

${ }^{8}$ Lihat Abū Hāmid al-Ghazālī, "Iljām al-'Awām 'an 'Ilm al-Kalām," dalam Majmū 'at Rasā'il al-Imām al-Ghazālì (Kaherah: Maktabah al-
} 
diatur sedemikian rupa, segalanya diciptakan dan diletakkan mengikut qaḍā' dan qadarNya, mengikut suatu aturan dan susunan yang disebut sebagai sunnatullāh, sehingga membentuk hirarki susunan semua makhluk dan termasuk di dalamnya hirarki dalam susunan manusia (hierarchy in the human order) ${ }^{9}$, yang dengan susunan ini maka terjelmalah keadilan Tuhan, dan manusia umpama alam kecil (mikrokosmos) yang mengandungi rahsia alam besar yang memenuhi jagat raya.

Dalam pandangan alam Islam, tiada sesuatu yang berlaku di dunia ini melainkan atas kehendak dan perintah Allah SWT, dan mengikut aturan dan sunnah yang telah ditentukan olehNya. Oleh yang demikian, kejadian manusia, lelaki ataupun perempuan, miskin mahupun kaya, pintar mahupun bodoh, demikian juga segala apa yang berlaku di dunia, turunnya hujan, terbit dan tenggelamnya matahari, gempa bumi, banjir dan taufan, perkara yang baik mahupun yang buruk adalah ketentuan, qaḍā' dan qadar, ataupun taqdir Allah SWT. Meskipun manusia berusaha sedaya upaya untuk mengelakkan perkara buruk daripada berlaku namun jika telah menjadi suratan taqdir maka kehendak Allah akan mengatasi kehendak manusia. Apa yang tercatat di lauh maḩüz akan berlaku meskipun manusia tidak menginginkannya dan berusaha untuk menghalangnya.

Oleh kerana itu, seseorang itu kekal lelaki meskipun ia ingin menjadi perempuan, dan seseorang itu kekal perempuan meskipun ia ingin menjadi lelaki. Perubahan apapun yang dilakukan terhadap dirinya hanya merupakan perubahan luaran, hakikat diri dan identitinya tetap tidak berubah. Justeru dengan melakukan perubahan pada dirinya yang tidak sesuai dengan identiti dan fitrahnya itu

Tawfiqiyyah, t.t.), 337; S.M.N. al-Attas, Prolegomena to the Metaphysics of Islam (Kuala Lumpur: ISTAC, 1995).

${ }^{9}$ Lihat S.M.N. al-Attas, Islam and Secularism (Kuala Lumpur: ISTAC, 1993), 107-8. 
maka ia telah menentang kehendak Allah dan melakukan kerosakan pada dirinya sendiri. Kerosakan yang dilakukan oleh manusia terhadap dirinya dan terhadap alam sekitar hanya akan menimbulkan lebih banyak kesengsaraan dalam kehidupan.

Fitrah yang ditetapkan oleh Allah SWT kepada manusia memberikan mereka jalan untuk melakukan sesuatu yang baik bagi dirinya dan persekitarannya. Dengan mengikuti fitrahnya manusia dapat berfungsi dengan baik sebagai hamba dan khalifah Allah SWT, dan kerananya mencapai kebahagian di dunia dan di akhirat. Lelaki diberikan fitrah untuk memimpin keluarga dan mencari nafkah, manakala perempuan diberikan fitrah untuk mengandungkan dan membesarkan anak. Apabila kedua pihak, suami dan isteri menuruti fitrah kejadian masing-masing maka berlaku keharmonian dan kebahagiaan.

Fitrah lelaki dan perempuan yang digambarkan di atas adalah benar apabila secara jujur diperhatikan sifat dan kecenderungan lelaki dan perempuan yang secara tabi'i memilikinya tanpa mengira bangsa, kaum, latarbelakang, dan bukannya dikondisikan oleh masyarakat seperti mana yang didakwa oleh golongan feminis. Malahan, sifat sedemikian wujud pada bangsa yang tidak bertamadun dan tidak beragama sekalipun. Maka sesuatu yang mustahil dan tidak masuk akal bahawa lelaki di seluruh dunia bersepakat untuk mencipta sifat-sifat di atas dengan tujuan untuk menindas kaum perempuan.

\section{Kekeliruan Golongan Feminis Muslim}

Gerakan feminisme pada umumnya merupakan suatu perjuangan bagi memerdekakan dan membebaskan kaum wanita daripada penindasan dan ketidakadilan yang dilakukan oleh kaum lelaki. Gerakan ini memainkan peranan yang penting di Eropah dan di Barat umumnya kerana dengan perjuangan golongan feminis ini, kaum 
wanita di Barat telah dapat mengecapi kemerdekaan dan kesamarataan yang sebelumnya dinafikan.

Penulis Inggeris, Mary Astell (1666-1731) mengungkapkan kemarahannya berkenaan ketidakadilan yang berlaku dengan katanya ${ }^{10}$ :

"If men are born free, how is it that all women are born slave?"

Terjemahan: "Jika lelaki dilahirkan merdeka, mengapa semua perempuan dilahirkan sebagai hamba?"

Ia sesuatu yang sebenarnya menggambarkan keadaan ketika itu di Eropah dan bukan di serata dunia, dan pastinya bukan di dunia Islam. Di Eropah, perempuan tidak memiliki hak pemilikan harta sebagaimana lelaki, hak perundangan untuk perempuan yang dizalimi sangat terbatas manakala universiti di Eropah tidak membenarkan perempuan mendapatkan pendidikan. Keadaan bertambah parah apabila kalangan ahli falsafah Barat sehingga zaman pencerahan, seperti Immanuel Kant (1724-1804) dan Jean Jacques Rousseau (1712-1778), mendokong diskriminasi dan merendahkan martabat wanita. ${ }^{11}$ Hanya ketika Maria Theresa di Austria (memerintah 1740-1780) dan Catherine the Great di Rusia (memerintah 1762-1796) menjadi ratu maka masyarakat Barat baru membuka mata terhadap keupayaan kaum wanita.

Walau bagaimanapun kaum wanita di Barat perlu berjuang habis-habisan untuk mendapatkan hak mereka

${ }^{10}$ Mary Astell, Political Writings, ed. Patricia Springborg (Cambridge: Cambridge University Press, 1996), 18. Lihat juga bukunya Some Reflection upon Marriage yang menganggap perkahwinan sebagai satu bentuk perhambaan (slavery). Mary Astell, Some Reflection upon Marriage (London: John Nutt, 1700) .

${ }^{11}$ Rousseau sebagai contoh menganggap pendidikan wanita hanya perlu sebagai persiapan bagi berkhidmat kepada lelaki. Lihat Julie; or, The New Heloise (1761) dan Emile; or, Education (1762). Lihat W. M. Spellman, A Short History of Western Political Thought (London: Palgrave-Macmillan, 2011), 106. 
yang dinafikan. Pada tahun 1789 ketika revolusi Perancis, terdapat tuntutan 'Petition of Women of the Third Estate to the King,' yang menuntut hak mendapatkan pendidikan dan pekerjaan. Tuntutan mereka malah mendapat tanggapan negatif daripada National Assembly yang menetapkan bahawa wanita perlu menjadi warganegara yang pasif, dan tidak layak untuk mengambil bahagian dalam pilihan raya.

Pada tahun 1792, Mary Wollstonecraft (1759-1797) menulis buku $A$ Vindication of the Rights of Woman yang menyatakan bahawa kemampuan intelektual wanita yang dikatakan lemah itu adalah natijah daripada pendidikan yang tidak adil dan nilai-nilai masyarakat yang tidak sihat. ${ }^{12}$ Beliau menuntut agar wanita muncul sebagai manusia yang rasional dan berdikari, yang hanya berlaku dengan memperbaiki pandangan diri sendiri untuk lebih dihormati. Usaha beliau ini diremehkan oleh ramai orang ketika itu.

Apa yang berlaku di Eropah pada abad pertengahan sebenarnya berakar pada falsafah Hellenistik yang sememangnya memandang rendah kepada perempuan. Sejak zaman Aristotle telah berlaku diskriminasi terhadap perempuan. Menurut Aristotle (322BC) akal wanita lemah, tidak mampu berfikir dengan waras dan rasional oleh kerananya wanita perlu dipimpin oleh lelaki. ${ }^{13}$ Hellenisasi Barat, termasuk Hellenisasi Kristian, meneruskan dasar diskriminasi dan penindasan terhadap wanita.

Pada hari ini golongan feminis umumnya bersepakat bahawa gender lelaki dan perempuan merupakan binaan masyarakat (social construct). Ia terhasil daripada harapan masyarakat (social expectation) dan cara seseorang itu dibesarkan. Simone de Beauvoir (1908-1986) adalah antara feminis pertama yang menegaskan hal ini apabila berkata:

12 Mary Wollstonecraft, A Vindication of the Rights of Woman (Dublin: J. Stockdale, 1793), 19.

13 Menurut Aristotle lagi, "women exist as natural deformities or imperfect males". Aristotle, Politics, terj. Ernest Barker (Oxford: Clarendon Press, 1948), 1254b, 13-16. 
"one is not born, but rather becomes woman", dan "social discrimination produces in women moral and intellectual effects so profound that they appear to be caused by nature". ${ }^{14}$ Jika perbezaan jantina (biological sex) dianggap sesuatu yang datang semula jadi oleh kerananya tidak dapat diubah, perbezaan gender pula, bagi mereka, adalah sesuatu yang dibentuk oleh masyarakat dan oleh kerananya tidak mesti diterima.

Di dunia Islam, tokoh-tokoh modenis adalah golongan yang memperkenalkan idea kesetaraan gender yang berasal daripada Barat. Muhammad 'Abduh (1849-1905), ketika mentafsirkan ayat 238 daripada surah al-Baqarah, menegaskan: "Ini adalah kaedah umum yang menjelaskan bahawa perempuan adalah sama dengan lelaki dalam semua hak. Kerana itu lelaki dan perempuan serupa pada zat, perasaan, dan akal". Namun "Abduh juga mengakui apabila berlaku perbezaan pendapat maka pandangan lelaki perlu didahulukan. ${ }^{15}$

Wacana kesetaraan gender ini kemudian dilanjutkan oleh Qāsim Amin (1863-1908), seorang modenis dan sahabat Muhammad 'Abduh. Di dalam Tahrīr al-Mar'ah (1899), beliau mengatakan bahawa perempuan dan lelaki sebenarnya adalah sama dari segi kekuatan fizikal, yang menjadikan mereka berbeza adalah kerana perempuan tidak menggunakan potensi jasad dan akal mereka secara optimum. Kerana itu menurut Qāsim Aminn, perempuan perlu membebaskan diri mereka daripada segala kongkongan yang membelenggu dirinya, termasuklah

${ }^{14}$ Simone de Beauvoir, The Second Sex (New York: Vintage Books, 2011 [original 1949]), 283, 14; Alison Stone, An Introduction to Feminist Philosophy (Cambridge: Polity Press, 2007), 2.

${ }^{15}$ Lihat Muhammad 'Imārah, al-Islām wa al-Mar'ah fi Ra'y al-Imām Muhammad 'Abduh (Kaherah: Nahdat Misr, 2007), 23. Lihat juga keterangan Ignaz Goldziher yang mengetengahkan metodologi pentafsiran modenis Muhammad 'Abduh dalam Madhāhib al-Tafsīr al-Islāmī, terj. 'Abd al-Halīm Najjār (Kaherah: Maktabah alKhanji,1955), 350-395. 
hijab. Hijab yang dipaksakan ke atas wanita, menurut beliau, hanya menghalang wanita dan masyarakat Islam daripada kemajuan dan pendidikan wanita hanya sempurna apabila mereka membuang hijab. ${ }^{16}$

Qāsim, sebagai seorang modenis, mempunyai kepercayaan yang mendalam terhadap idea-idea Barat. Beliau tidak sedar bahawa apa yang dilakukannya boleh membawa natijah yang buruk kepada masyarakat Islam. Dengan tujuan islah, beliau tanpa segan silu mencanangkan idea-idea Barat. Qāsim melihat masyarakat Barat, khususnya bangsa Anglo-saxon sebagai model kemajuan. ${ }^{17}$ Persoalannya mengapa muncul penulis Muslim yang memperbesarkan persoalan hijab? Mengapa tumpuan diberikan kepada kedudukan perempuan dalam masyarakat Islam? Apakah ada agenda di sebalik pembebasan perempuan? Sememangnya wujud agenda kolonialisme di sebalik wacana pembebasan wanita. Ia sebagaimana diterangkan oleh Katherine Bullock, orientalis dan penulis Barat yang melihat bahawa penjajahan terhadap bangsa lain merupakan misi pentamadunan. Menurut Bullock penghapusan hijab dilihat oleh Barat sebagai bahagian penting dalam misi pentamadunan Barat. $^{18}$

${ }^{16}$ Qāsim Amīn, Taḥrīr al-Mar'ah, (Kaherah: Nawabigh al-Fikr, t.t), pada muka surat 62 dan 63 beliau mengatakan:

أن المرأة لا تكون ، ولا يمكن أن تكون، وجودا تاما إلا إذا ملكت نفسها وتمتعت بحريتها الممنوحة لما بمقتضى الشرع والفطرة معا ونمت ملكاتما إلى أقصى درجة يمكنها أن تبلغها، ويرى

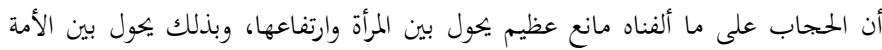

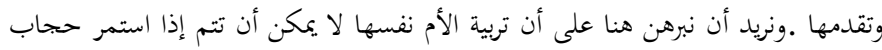
النساء على ما هو عليه الآن.

${ }^{17}$ Ibid., 94.

${ }^{18}$ Katherine Bullock, Rethinking Muslim Women and the Veil (Virginia: IIIT, 2010), 25. 
Evelyn Baring, First Earl of Cromer (1841-1917), yang memerintah Mesir pada abad ke-19, berkata $^{19}$ :

"The position of women in Egypt is a fatal obstacle to the attainment of that elevation of thought and character which should accompany the introduction of European civilisation".

Beliau juga menegaskan bahawa cabaran bagi orang Barat yang sebenarnya adalah untuk mengangkat martabat wanita di dunia Islam ${ }^{20}$ :

"To graft true civilisation on a society which is but just emerging from barbarism...not only to educate but to elevate the women, he will never succeed in affording to the man, in any thorough degree, the only education which is worthy of Europe".

Maka dapat disimpulkan bahawa misi pembebasan wanita sebenarnya bukanlah idea asli daripada penulispenulis Muslim, tetapi datang daripada penulis Barat yang sekaligus pemerintah kolonial mereka, yang sudah tentunya membawa agenda kolonialisme. Hal ini dapat dilihat daripada kata-kata Cromer sendiri ${ }^{21}$ :

"The new generation of Egyptians has to be persuaded or forced into imbibing the true spirit of Western civilisation".

Pernyataan Cromer ini disahkan juga oleh seorang pegawai tentera Perancis yang menulis pada tahun $1846^{22}$ :

"When we have them in our hands, we will then be able to do many things which are quite impossible for us today and which will perhaps

\footnotetext{
${ }^{19}$ Evelyn Baring, First Earl of Cromer, Modern Egypt, 2 vols. (London: Macmillan, 1908), 2:538.

${ }^{20}$ Ibid., 2:542.

${ }^{21}$ Ibid., 2: 538.

${ }^{22}$ Seperti dikutip oleh Mitchell, Colonising Egypt, 95.
} 
allow us to capture their minds after we have captured their bodies".

Selanjutnya wacana kesetaraan gender ini juga mendapat perhatian Fazlur Rahman (1919-1988). Dalam bukunya Major Themes of the Qur'an, beliau mengatakan bahawa lelaki dan wanita adalah setara, iaitu suami tidak lebih berkuasa ke atas isterinya. ${ }^{23}$ Golongan feminis pada umumnya tidak menerima ayat al-Qur'an yang menegaskan kepimpinan lelaki dalam rumahtangga. Mereka lebih cenderung untuk menterjemahkan qawwāmūn sebagai pencari nafkah (breadwinners). ${ }^{24}$

Istilah breadwinner ini bermasalah kerana ia telah menyempitkan peranan suami kepada fungsi ekonomi. Perlu ditegaskan bahawa perkataan qawwām tidak terhad kepada pemberian nafkah, sebagaimana akan dijelaskan di bawah, lelaki menjadi pemimpin bukan hanya kerana lelaki memberi nafkah, tetapi kerana lelaki diberi amanah dan tanggungjawab untuk memastikan rumahtangga termasuk isterinya, dijaga dan dipelihara dengan baik mengikut kehendak Allah. Maka ketika isteri tidak memerlukan nafkah material lelaki, tidak bermakna isteri tidak perlu taat pada suami. Di sini jelas bahawa Fazlur Rahman telah melakukan kesilapan apabila mengatakan bahawa ketika seorang isteri berhasil mandiri dan memberi sumbangan kepada rumahtangga maka kuasa suami keatasnya berkurangan ${ }^{25}$ :

"Wife's economic self-sufficiency... and contribution to the household reduces the husband's superiority, since as a human, he has no superiority over his wife."

Tokoh feminis sekular seperti Fatima Mernissi berpandangan bahawa hijab merupakan hasil kesepakatan

23 Fazlur Rahman, Major Themes of the Qur'an (Minneapolis: Bibliotheca Islamica, 1980), 48.

${ }^{24}$ Ibid.

${ }^{25}$ Ibid., 49. 
masyarakat, social construct, dan merupakan cerminan penguasaan golongan lelaki terhadap wanita. Dalam bukunya Beyond the Veil(1975), Fatima Mernissi mengatakan bahawa hijab adalah simbol penindasan ke atas kaum wanita (the veil as a tool and symbol of oppression and subservience). ${ }^{26}$ Dalam bukunya yang lain, The Veil and the Male Elite, beliau mengatakan bahawa kewajipan hijab bukan daripada Nabi, tetapi merupakan pandangan para sahabat yang memiliki sifat membenci kaum wanita (misogynists) yang tidak ingin wanita menjadi pemimpin masyarakat. Malah amalan hijab menurutnya adalah tradisi Arab jahiliyyah. ${ }^{27}$ Sebagaimana Qāsim Amīn, beliau membuat kesimpulan bahawa pembebasan wanita Islam tidak akan berlaku tanpa penolakan terhadap hijab.

Pandangan sekular terhadap hukum Islam juga terlihat dalam wacana yang diketengahkan oleh Amina Wadud. Di dalam bukunya Qur'an and Woman (1992), Wadud melihat bahawa wanita dalam Islam tertindas, dianggap sebagai manusia yang bertaraf rendah (inferior), secara tabi'inya jahat, memiliki tahap intelektual yang rendah dan lemah beragama. Semua pandangan negatif terhadap perempuan ini berpunca daripada tafsiran terhadap al-Qur'an yang dikuasai oleh kaum lelaki. Oleh kerana itu al-Qur'an perlu ditafsirkan semula daripada perspektif wanita, dengan mengikut kaedah hermeneutik. ${ }^{28}$ Beliau turut menyanggah adanya hirarki dalam Islam.

${ }^{26}$ Fatima Mernissi, Beyond the Veil (London: Al Saqi Books, 1985), 82.

27 Fatima Mernissi, The Veil and the Male Elite: A Feminist Interpretation of Women's Rights in Islam (New York: Basic Book, 1991), 81.

${ }^{28}$ Amina Wadud menjelaskan: "we are the makers of textual meaning. The result of our meaning-making is the reality we establish from those meaning to human experience and social justice. We need to make the text mean more for women's full human dignity than it has been conceived to do or applied toward at any other time in Muslim history". Amina Wadud, Inside the Gender Jihad (Oxford: Oneworld Publication, 2006), 204. 
Wadud menegaskan bahawa lelaki dan wanita perlu dilihat sama rata (equal) ${ }^{29}$ :

"Women are equal to men, they have the same rights and obligations on the ethico-religious level and have equally significant responsibilities on the social functional level".

Kerana itu beliau menolak konsep lelaki sebagai ketua rumah tangga (qawāmah), perempuan tidak boleh menjadi imam solat berjama'ah dan lain-lain lagi. Baginya para ulama' yang mentafsirkan al-Qur'an sepanjang sejarah telah bertindak bias, berat sebelah dan mengamalkan budaya patriarki dalam merumuskan hukum Islam. ${ }^{30}$

Walaupun pada hakikatnya Islam sebagai agama yang disampaikan dan diajarkan oleh Rasulullah tidak pernah menindas kaum wanita, namun demikian amalan sesetengah masyarakat Islam yang cenderung merendahkan dan mendiskriminasikan kaum wanita telah sedikit sebanyak memburukkan imej Islam. Wujudnya 'penindasan' ini telah menyebabkan kemunculan kelompok feminis Muslim seperti Fatima Mernissi yang memperjuangkan agenda pembebasan wanita, dan mereka melihat bahawa hijab, dengan pentafsiran yang melampau itu, adalah simbol penindasan terhadap kaum wanita.

Sanggahan Fatima Mernissi terhadap hijab timbul akibat kekeliruan tentang perbezaan hijab sebagai suatu konsep dengan niqāb, purdah, burqa' yang merupakan suatu tafsiran kepada hijab. Terdapat ulama' khususnya dari kalangan Pseudo-Salafi yang menegaskan kewajipan purdah, niqāb atau abaya. ${ }^{31}$ Pemaksaan pemakaian purdah

29 Amina Wadud, Qur'an and Woman (Kuala Lumpur: Fajar Bakti, 1992), 102.

${ }^{30}$ Lihat Amina Wadud, Qur'an and Woman, 2; lihat juga Ziba MirHosseini, Islam and Gender: The Religious Debate in Contemporary Iran (New York: Princeton University Press, 1999).

${ }^{31}$ Mengenai kewajipan niqāb, pakaian yang menutup muka dan tangan, lihat fatwa Ibn Taymiyyah, Hijāa al-Mar'ah wa Libāsuha fi al-Șalāh 
terhadap wanita menjustifikasikan gerakan feminisme untuk membebaskan wanita daripada penindasan kaum lelaki. Sebenarnya tiada dalil yang mewajibkan purdah, niqāb, burqa' atau abaya ke atas wanita. Yang ada hanyalah kewajipan menutup aurat yang dengannya seseorang wanita dianggap telah berhijab. Majoriti ulama berpendapat bahawa menutup muka dan tangan bukanlah suatu kewajipan kerana terdapat dalil yang menunjukkan bahawa tangan dan muka bukan aurat wanita. Nabi sendiri tidak pernah mewajibkan wanita untuk menutup muka dan tangan. ${ }^{32}$

Kesilapan sebahagian orang Islam, termasuk yang digelar sebagai ulama', telah menyebabkan Islam ikut terpalit dengan penindasan dan diskriminasi. Walaupun sebenarnya majoriti ulama' tidak mewajibkan purdah, tetapi pandangan minoriti inilah yang diketengahkan untuk memberikan imej yang buruk terhadap Islam. Kelompok Pseudo-Salafi tidak sedar bahawa dengan mewajibkan purdah dan abaya, mereka telah meletakkan tanggungjawab menjaga kehormatan terhadap kaum wanita sahaja, walhal al-Qur'an menyuruh lelaki juga untuk menjaga kehormatan kaum wanita dengan menundukkan pandangan.

Seseorang itu tidak perlu menundukkan pandangan jika tiada apa yang ingin dilihat. Justeru oleh kerana adanya keinginan untuk melihat lalu ia berupaya menahannya demi

(Riyadh: Maktabah al-Ma‘ārif,t.t.),11; Ibn Bāz, Risālah Tabhath fī Masā'il al-Hijāb wa al-Sufur (Madinah: al-Jāmi'ah a-Islāmiyyah, t.t.). Șāliḥ bin 'Uthaymin, Risālat al-Hijāb (Madinah: al-Jāmi'ah aIslāmiyyah, t.t.)., 12-13. Pandangan yang berbeza dikemukakan oleh Nāṣir al-Dīn al-Albāni sendiri, lihat Jilbāb al-Mar'ah al-Muslimah fi al-Kitāb wa al-Sunnah (Beirut: Dār al-Salām, 2002). Perbahasan tentang kewajipan niqāb boleh dirujuk di pautan berikut: Nuruddeen Lemu, Is the Niqab Wajib for All Muslim Women? https://thethinkingmuslim.com/wpcontent/uploads/2014/05/niqab1.pdf.

32 Lihat al-Zuhayli, al-Fiqh al-Islāmi wa Adillatuh (Beirut: Dār alFikr, 1994), 4:2651-2. 
menjaga kehormatan orang yang dilihat dan memelihara diri sendiri. Maka, di sinilah letaknya tujuan dan hikmah disebalik suruhan menundukkan pandangan. Tanpanya tiada kewajaran pada suruhan tersebut. Tugas menjaga kehormatan perlu diletakkan kepada kedua belah pihak dan bukan hanya kepada satu pihak sahaja. Inilah keadilan Islam yang perlu diserlahkan dan tidak boleh dicemarkan dengan pandangan-pandangan yang tidak mencerminkan keadilan dan keindahan Islam.

Apabila terbukti bahawa amalan penindasan yang dilakukan terhadap wanita oleh golongan konservatif Pseudo-Salafi hanyalah pentafsiran keliru mereka sendiri terhadap Islam dan ia sebenarnya bukanlah tafsiran yang sah terhadap Islam, maka sebenarnya tidak ada alasan bagi golongan feminis untuk merombak dan mentafsirkan semula Islam untuk disesuaikan dengan idealisme feminisme.

Kedua-dua pendekatan konservatif dan feminis (liberal) adalah ekstrim, sedangkan kefahaman Islam yang dikemukakan oleh para ulama' Ahl al-Sunnah wa alJamā'ah adalah kefahaman yang adil, pertengahan serta jauh daripada ekstrimisme. Pendekatan Sunni ini bercirikan pertengahan(wasațiyyah), di mana terdapat perkara-perkara yang thawābit (kekal tidak berubah) dan perkara-perkara yang mutaghayyirāt (dinamik dan sentiasa berubah). Dengan wujudnya pergerakan teguh (dynamic-stabilism $)^{33}$ ini maka masyarakat Islam yang berpegang kepada pendekatan Ahl al-Sunnah wa al-Jamā'ah ini tidak hanyut sebagaimana kaum liberal dan tidak jumud sebagaimana kaum konservatif dan radikal.

33 Lihat penerangan tentang istilah dynamic-stabilism ini oleh Wan Mohd Nor Wan Daud, Islamization of Contemporary Knowledge and the Role of the University in the Context of De-Westernization and Decolonization (Johor Bahru: Penerbit Universiti Teknologi Malaysia, 2013), 20. 
Apabila tiada penindasan terhadap wanita di dalam Islam maka tiada kewajaran bagi kewujudan feminisme dalam Islam. Adapun wujudnya penindasan, ketidakadilan dan diskriminasi terhadap wanita dalam masyarakat Islam, ia bukanlah sesuatu yang unik dalam masyarakat Islam. Setiap masyarakat yang mundur menghadapi masalah ketidakadilan. Ketidakadilan yang berlaku dalam masyarakat Islam tidak bersangkut paut dengan agama Islam, kerana apabila ditelusuri secara mendalam ia adalah masalah kondisi manusia yang tidak beretika. Masyarakat Islam mengalami kemunduran dari pelbagai segi sama ada moral, rohani, aqli, pendidikan, ekonomi dan politik.

Oleh kerana itu ketidakadilan berlaku dalam masyarakat. Ia bukan hanya berlaku terhadap wanita malah terhadap kanak-kanak, orang tua, orang miskin, bahkan semua kelompok yang lemah. Dengan memahami konteks masalah ini maka kita dapat melihat feminisme bukanlah jawapan kepada masalah ketidakadilan yang berlaku ke atas kaum wanita. Justeru kewujudan mereka dalam masyarakat Islam hanya menimbulkan lebih banyak masalah dari segi akidah dan pemikiran di kalangan orang Islam.

Jika perempuan mengalami penindasan di Barat, apa yang berlaku di dunia Islam adalah sebaliknya. Diskriminasi dan ketidakadilan tidak pernah menjadi masalah besar dalam masyarakat Islam. Justeru, Islam telah menjamin kebebasan individu, dan kemuliaan setiap insan, termasuk wanita dan hamba sahaya. Islam mewajibkan lelaki dan perempuan untuk menuntut ilmu. ${ }^{34}$ Bahkan sejak zaman Rasulullah s.a.w. telah muncul cendekiawan wanita, seperti 'A'īshah (613-678), Umm Salāmah (596-683) dan Hafșah (605-665), yang mengajarkan agama kepada kaum wanita khususnya.

${ }^{34}$ Hadith Rasulullah s.a.w: "Menuntut ilmu adalah kewajipan ke atas setiap Muslim (lelaki dan perempuan)" Hadith riwayat Ibn Mājah no: 224. 
Bahkan terdapat masjid yang ditubuhkan oleh seorang wanita, iaitu Fatimah al-Fihriyyah (800-880). Masjid dan universiti ini kini dikenali sebagai universiti tertua di dunia yang masih wujud sehingga ke hari ini, iaitu Universiti Qarawiyyin di Fez, Maghribi. Di zaman Sayyidina Umar pula wanita telah memainkan peranan yang besar dalam aspek sosial dan ekonomi apabila al-Shifā' binti 'Abd Allāh, sahabat Nabi di kalangan wanita, telah dilantik oleh Khalifah 'Umar sebagai pegawai Hisbah di pasar, setaraf menteri perdagangan pada masa ini. ${ }^{35}$ Pada abad ke-17 di alam Melayu terdapat ratu yang memerintah kerajaan Aceh Darussalam. ${ }^{36}$

Walaubagaimanapun, Islam meletakkan peranan lelaki dan perempuan berbeza. Rasulullah melarang wanita daripada berperang tetapi hanya dibenarkan untuk membantu dan merawat di belakang medan perang. Ketika baginda ditanya mengenai perbezaan ini maka turun ayat yang menjelaskan agar kaum perempuan tidak mempersoalkan perbezaan peranan ini, kerana masingmasing memiliki tanggungjawab yang berbeza. ${ }^{37}$

\section{Fitrah dan Gender}

Sebagaimana hakikat dan fitrah manusia telah ditentukan oleh Allah SWT sebelum manusia diciptakan, demikian pula sifat gender lelaki dan perempuan. Sifat gender dan peranan keduanya telah ditentukan sejak sebelum mereka lahir di dunia. Manusia diciptakan berbeza bukan sahaja dari segi biologi, memiliki jantina dan fisiologi yang berbeza, tetapi mereka diciptakan dengan fungsi sosial

35 Beliau adalah al-Shifā' binti 'Abd Allāh bin Shams al-'Adawiyyah, seorang yang pintar membaca dan menulis, dan guru kaligrafi di zaman Rasulullah. Lihat Ahmad bin 'Alì al-Maqrīzí, Imtā ' al-Asmā' (Beirut: Dār al-Kutub al-'Ilmiyyah, 1999), 9:395. Untuk biografi beliau, lihat juga Ibn Hajar al-'Asqalani, al-Ișābah fi Tamyīz alȘaḥābah (Beirut: Dār al-Kutub al-'Ilmiyyah, 1995),7:728.

${ }^{36}$ Lihat Denys Lombard, Kerajaan Aceh (Jakarta: KPG, Ecole francaise d'Extreme-Orient, 2008), 254.

${ }^{37}$ Lihat surah al-Nisā', 32 . 
yang berbeza kerana memiliki sifat, kecenderungan, keinginan, dan peranan yang berbeza. Oleh kerana lelaki dan perempuan memiliki fitrah yang berbeza, maka Islam menetapkan bahawa lelaki dan perempuan memiliki peranan yang berbeza, dan peranan ini telah ditetapkan oleh Allah dan menjadi sebahagian daripada Syari' ah yang tidak berubah mengikut peredaran zaman.

Perkataan fitrah dalam bahasa Arab berasal dari akar kata fațara yang bermaksud mencipta (ibtada 'a) daripada sesuatu yang tidak ada. Kerana itu di dalam al-Qur'an, Allah SWT disebut sebagai Fātir yakni Pencipta yang agung. ${ }^{38}$ Menurut para ulama' ahli Bahasa, fitrah bermaksud asal kejadian (khilqah) manusia, yang selalu disebut sebagai sifat-sifat semula jadi (natural disposition). Merujuk kepada ayat al-Qur'an, "fițratallāh allati fațara alnāsa 'alayhā," dan hadith "Kullu mawlūdin yūladu 'ala alfitrah," al-Zamakhsharī dalam Asās al-Balāghah menambahkan bahawa fitrah di sini merujuk kepada perwatakan yang cenderung kepada agama yang benar (aljibillah al-qābilah li dīn al-haq). ${ }^{39}$

Demikian juga al-Rāghib al-Asfahani dan al-Zabīdi berkata bahawa fitrah adalah penciptaan Allah SWT dalam diri manusia yang menjadikannya bersedia untuk melakukan sesuatu. Beliau juga menguatkan pendapatnya ini dengan ayat 25 surah Luqmān yang menjelaskan bahawa pada dasarnya kaum musyrikin pun tahu bahawa Pencipta alam semesta adalah Allah SWT. ${ }^{40}$

38 Al-Qur'an surah Fāțir, 1: "Segala puji tertentu bagi Allah yang menciptakan langit dan bumi, yang menjadikan malaikat utusanutusan yang bersayap: dua, tiga dan empat; Ia menambah pada bentuk kejadian makhluk yang diciptakanNya apa jua yang dikehendakiNya. Sesungguhnya Allah Maha Kuasa atas tiap-tiap sesuatu".

39 Muḥammad bin 'Umar al-Zamakhshari, Asās al-Balāghah (Beirut: Dār al-Kutub al-'Ilmiyyah, 1998), 2:28.

40 Al-Rāghib al-Asfahanī, Mufradāt Alfāz al-Qur'ān (Damshiq: Dār alQalam, 2011), 640; Muḥammad Murtậā al-Zabīīi, Tāj al-'Arūs (Beirut: Dār Sadir, 2011) 8:178. 
Bagi seorang mu'min, sifat Qudrah dan Irādah Allah SWT adalah mutlak sedangkan kuasa dan keinginan manusia hanyalah berlaku dengan izinNya. Disebut sebagai fitrah kerana sesuatu yang diciptakan itu mengikut acuan yang diinginkan oleh penciptaNya. Maka apabila sesuatu ciptaan tidak mengikuti sifat kejadiannya yang diingini oleh Penciptanya ia boleh dianggap suatu keingkaran. Sesuatu yang mengikut fitrahnya pula disebut sebagai tabi'i, (natural). Tabi'i daripada perkataan Arab, țaba'a bermaksud mencetak, menjadikan sesuatu dengan rupa tertentu yang kekal.

Al-Jurjāni ketika merujuk kepada manusia dan perkataan al-țab', menurutnya bermaksud apa yang terbit daripada manusia tanpa kemahuan. ${ }^{41}$ Al-Rāghib alAsfahani menyebut bahawa al-tab ' adalah kecenderungan yang diciptakan oleh Allah dalam diri manusia. Alam tabi'i ('álam al-tabi'sah) merujuk kepada alam yang mengikut acuan dan kehendak Allah SWT. Kerana itu alam ini merupakan cetakan (sibgah) Allah, di mana jelas terdapat kesan atau bekas (impression), yang menunjukkan keagungan dan kebijaksanaan Penciptanya.

Maka dapat disimpulkan bahawa mengikut pandangan alam Islam, segala ciptaan Tuhan secara tabi' inya mengikut kehendak, keinginan dan acuan Tuhan (sunnatullāh). Rekaan ini adalah yang terbaik dan sempurna kerana dibuat dengan ilmu dan kebijaksanaan yang tiada tara, kerana itu ia tidak akan pernah berubah. ${ }^{42}$ Antara rekaanNya adalah bahawa kaum lelaki mempunyai sifat, perwatakan dan keupayaan yang berbeza daripada kaum perempuan. Kedua-dua gender dan jantina adalah ciptaan dan ketentuan Allah.

\footnotetext{
41 Al-Jurjāni, Kitāa al-Ta'rīfât, ed. Muḥammad Șiddīq al-Minshāwī (Kaherah: Dār al-Faḍilah, t.t.), 119. Adapun tabì ‘ $a h$ menurut beliau adalah kekuatan yang berada dalam jisim dengannya sesuatu itu dapat mencapai kesempurnaannya yang tabi'i.

${ }^{42}$ Al-Qur'an surah al-Aḥzāb: 38.
} 
Gender adalah sifat pembawaan dan kecenderungan semulajadi kurniaan Tuhan yang berbeza mengikut jantina. Seorang lelaki, sebagai contoh, sukakan perempuan. Perasaan suka ini berlaku secara tabi'i atau natural. Sebaliknya apabila seorang lelaki sukakan lelaki maka ia adalah sesuatu yang dianggap luar tabi'i. Kita dapat melihat bahawa perwatakan yang berbeza antara lelaki dan perempuan berlaku ketika kecil, seumur 2-3 tahun lagi, di mana anak lelaki pada umumnya akan menyukai harimau atau singa sebagai binatang kesukaan, sedangkan anak perempuan akan menyukai kucing, rusa, kanggaru dan seumpamanya. Ini menunjukkan kecenderungan mereka yang berbeza sejak lahir, dan bukan pengaruh persekitaran.

Kita juga dapat melihat bahawa apabila tumbuh dewasa, kaum perempuan umumnya suka mengemas, bersolek, sukakan kecantikan dan sebagainya. Sifat dan kecenderungan ini timbul dalam diri seseorang perempuan secara tabi'i. Seseorang wanita yang tidak memiliki perwatakan wanita bukanlah wanita yang normal, tidak terjadi secara tabi'i, tetapi muncul akibat faktor luaran. Demikian juga sebaliknya. Kerana itu Tuhan tidak menciptakan seorang lelaki yang gay dan perempuan yang lesbian, tetapi manusia itu sendiri yang memilih untuk menjadi gay dan lesbian.

Lelaki dan wanita, menurut perspektif Islam khususnya dan masyarakat beragama umumnya, bukan sahaja berbeza kerana mereka memiliki alat kelamin yang berbeza tetapi juga berbeza dari segi esensinya, kerana masing-masing memiliki sifat, kecenderungan dan kemampuan yang berbeza. Perbezaan pada aspek-aspek inilah yang disebut sebagai fitrah. Konsep kesetaraan gender oleh kerana itu secara tidak langsung mengetepikan dan menolak wujudnya fitrah yang berbeza antara lelaki dengan perempuan. Perbezaan sifat, perwatakan, kecenderungan dan kemampuan ini wujud secara tabi'i (innate) dalam diri manusia. Ia adalah sunnatullāh dan 
fitrah yang Allah tetapkan kepada makhlukNya. Perbezaan fitrah antara lelaki dan perempuan ini berlaku secara tabi'i, bukan dibentuk oleh masyarakat dan persekitaran dan ini bermakna konsep gender yang diterima pakai oleh masyarakat Barat serta golongan feminis khususnya, adalah salah, keliru dan berbahaya.

Seorang manusia yang sedar bahawa gender adalah ketentuan Tuhan, tidak akan berani untuk merubah gendernya. Ia sedar bahawa ketentuan dan ketetapan Tuhan tidak akan berubah. Seorang lelaki akan tetap menjadi seorang lelaki meskipun ia dapat menukarkan alat kelaminnya kepada alat kelamin perempuan. Begitu juga sebaliknya. Yang membezakan lelaki dengan perempuan adalah esensi dan bukan sifat luaran. Seorang perempuan itu dikenali sebagai perempuan kerana keperempuanannya. Dan seorang lelaki dianggap lelaki kerana kelelakiannya.

Kelelakian dan keperempuanan inilah yang menjadi esensi lelaki dan perempuan dan bukan alat kelaminnya (jantina). Oleh itu apabila seseorang lelaki mendapatkan khidmat pembedahan untuk menukar alat kelaminnya ia pada hakikatnya tetap seorang lelaki. Seorang suami akan merasa tertipu apabila mengetahui bahawa ternyata perempuan yang dikahwininya sebenarnya adalah seorang lelaki, kerana secara tabi'inya seorang lelaki hanya tertarik kepada lawan jenis bukan sama jenis.

Dari segi kemanusiaan, setiap manusia adalah mulia dan terhormat, sama ada lelaki mahupun perempuan. ${ }^{43}$ Perangai dan tingkah laku manusia itu sendiri yang akan menyebabkannya dipandang hina oleh orang lain. Dalam pandangan Allah, hanya orang yang bertaqwa yang mendapat tempat yang tinggi di sisiNya. ${ }^{44}$ Seseorang itu tidak menjadi mulia atau hina kerana dia seorang lelaki

\footnotetext{
43 Dalam al-Qur'an, surah al-Isrā': 70, disebutkan bahawa anak-anak Adam telah dimuliakan oleh Allah SWT, dengan diberikan kelebihankelebihan yang tidak diberikan kepada makhluk yang lain.

${ }^{44}$ Surah al-Hujurāt: 13.
} 
ataupun perempuan, atau kerana dia berkulit hitam ataupun putih, atau menjadi pemimpin, kaya ataupun berkuasa. Ini kerana Islam meletakkan kemuliaan pada nilai yang bersifat spiritual, iaitu ketakwaan, keimanan dan juga ilmu yang dengannya ia dapat memberi manfaat kepada umat manusia. ${ }^{45}$

Dalam mengatur kehidupan suami isteri dan institusi keluarga, Syari'ah Islam mengambil kira perbezaan fitrah lelaki dan perempuan. Oleh kerana itu Islam meletakkan keduanya di tempat yang berbeza dengan peranan yang berbeza. Hanya apabila setiap satunya diberikan peranan yang berbeza maka akan berlaku keadilan, sebaliknya apabila keduanya disama-ratakan maka yang akan berlaku adalah ketidakadilan.

\section{Kepimpinan Lelaki ke atas Wanita (al-Qiwāmah)}

Berbeza dengan dakwaan golongan feminis, sebenarnya persoalan kepimpinan kaum lelaki ke atas kaum wanita adalah sesuatu yang telah ditegaskan dalam al-Qur'an. Ia bukan lahir dari amalan masyarakat tertentu, dan bukan juga hasil budaya. Kerana itu dalam tradisi Islam perkara ini merupakan sesuatu yang mapan (thābit) dalam agama dan bukan sesuatu yang berubah mengikut peredaran zaman. Namun begitu hakikat ini tidak dapat diterima oleh kaum feminis Muslim, kerana kepimpinan lelaki dilihat bertentangan dengan konsep kesetaraan gender yang mereka perjuangkan.

Beberapa ayat al-Qur'an menegaskan kepimpinan lelaki dalam rumahtangga,, antara lain dalam surah alNisā': 34 Allah berfirman yang maksudnya:

"Kaum lelaki itu adalah pemimpin dan pengawal (qawwāmūn) yang bertanggungjawab terhadap kaum perempuan, oleh kerana Allah telah melebihkan (faḍdalallāh) orang-orang lelaki (dengan beberapa keistimewaan) atas

${ }^{45}$ Surah al-Mujādalah: 11. 
orang-orang perempuan, dan juga kerana orangorang lelaki telah membelanjakan (memberi nafkah) sebahagian dari harta mereka. Maka perempuan-perempuan yang soleh itu ialah yang taat (kepada Allah dan suaminya), dan yang memelihara (kehormatan dirinya dan apa jua yang wajib dipelihara) ketika suami tidak hadir bersama, dengan pemuliharaan Allah dan pertolonganNya. Dan perempuan-perempuan yang kamu bimbang melakukan perbuatan derhaka (nusyuz) hendaklah kamu menasihati mereka, dan (jika mereka berdegil) pulaukanlah mereka di tempat tidur, dan (kalau juga mereka masih degil) pukullah mereka (dengan pukulan ringan yang bertujuan mengajarnya). Kemudian jika mereka taat kepada kamu, maka janganlah kamu mencari-cari jalan untuk menyusahkan mereka. Sesungguhnya Allah Maha Tinggi, lagi Maha Besar."

Sebagaimana dijelaskan di atas, perkataan qawwāmūn di dalam ayat ini menjadi bahan perdebatan. Terdapat usaha untuk mentafsirkan semula maknanya, dengan menolak tafsiran para ulama' terdahulu, agar selari dengan konsep kesetaraan gender. Perkataan qawwām berasal dari perkataan $q \bar{a}$ 'im yang bermaksud penanggungjawab, orang yang memelihara dan bertanggungjawab. Maka qawwām menurut al-Zabidi adalah penjaga dan pemelihara. Menurut beliau lagi, $q \bar{a}$ ' $i m$ juga bermaksud orang yang berdiri tegak di dalam kebenaran. ${ }^{46}$ Maka qawwām juga membawa makna, orang yang bertanggungjawab memastikan sesuatu itu berdiri di atas jalan kebenaran.

Fakhr al-Dín al-Rāzi dalam tafsirnya menjelaskan bahawa al-qawwām, berasal daripada ungkapan al-qā' 'im bi al-amr, iaitu nama atau gelaran yang merujuk kepada

${ }^{46} \mathrm{Al}$-Zabīīi, Tāj al- 'Arūs, 8:775. 
seseorang yang dipertanggungjawabkan dengan sesuatu tugas, ${ }^{47}$ kerana itu ia adalah pengurus, penanggungjawab dan pemimpin. ${ }^{48}$

Perkataan faddala sering diertikan dalam bahasa Inggeris dengan perkataan preferred. Ia memberi isyarat bahawa kaum lelaki lebih disenangi berbanding kaum perempuan, walhal hakikatnya tidak bermaksud demikian. Ia hanya menegaskan bahawa Allah SWT memberikan kaum lelaki sesuatu yang lebih berbanding perempuan. Seseorang yang diberi nikmat yang lebih tidak semestinya adalah orang yang lebih dikasihi, demikian juga seseorang yang diberikan musibah dan cubaan tidak bermakna ia dibenci oleh Allah. Ini kerana kedua-dua kelebihan dan kekurangan adalah ujian daripada Allah. Al-Qur'an juga menegaskan bahawa Allah SWT menciptakan manusia bertingkat-tingkat, sebahagian memiliki kelebihan ke atas sebahagian yang lain. ${ }^{49}$

Kita perhatikan juga di sini bahawa antara sebab mengapa Allah menggunakan perkataan qawwāmūn dan bukan ru'asā' atau umarā' yang bermaksud pemimpin, adalah kerana yang ingin ditekankan bukanlah kepimpinan itu sendiri sebagai suatu jawatan, tetapi pemimpin dalam erti orang yang bertanggungjawab menjaga keluarga. Justeru, ia harus dilihat sebagai suatu beban serta tanggungjawab yang akan dipersoalkan, dan bukan satu kedudukan semata.

47 Fakhr al-Dīn al-Rāzí, Mafātīḥ al-Ghayb (Beirut: Dār al-Kutub al'Ilmiyyah, 2009), tafsir surah al-Nisā', 34.

${ }^{48}$ Terjemahan yang diberikan oleh Sahih International adalah "Men are in charge of women". Ia terjemahan yang lebih tepat berbanding Yusuf Ali: "protectors and maintainers", Muhammad Asad: "take full care", Riffat Hasan: "managers". Wadud, Azizah: "breadwinners", "those who provide a means of support or livelihood". Lihat Asma Barlas, Believing Women in Islam: Unreading Patriarchal Interpretations of the Qur'an (Austin: University of Texas Press, 2002), 186-7.

${ }^{49}$ Lihat al-Zukhruf: 32. 
Fakhr al-Dīn al-Rāzí dalam mentafsirkan ayat 34 surah al-Nisā' menerangkan bahawa kelebihan lelaki berbanding perempuan yang dimaksudkan terbahagi kepada dua jenis: pertama, adalah sifat-sifat hakiki seperti ilmu (akal) ${ }^{50}$ dan kekuatan jasmani; kedua, pada hukum-hakam Syari'ah, seperti kepimpinan tertinggi, kepimpinan dalam solat, jihad, azan, khutbah, kesaksian dalam perkara hudud dan qișaș, kelebihan dalam harta waris, pembayaran diyat, wali nikah, talak, rujuk, dan hak nasab. ${ }^{51}$

Seterusnya ayat di atas juga menegaskan tuntutan agar isteri mentaati suami, dan apabila perkara ini gagal dipatuhi maka suami berhak mengambil tindakan yang sewajarnya kepada isteri. Perkara ini kemudian dijelaskan dalam banyak hadith yang menyatakan kewajipan isteri untuk taat kepada suami. ${ }^{52}$ Tuntutan untuk mentaati suami dalam ayat dan hadith jelas menunjukkan bahawa suami adalah ketua rumahtangga yang bertanggungjawab untuk menjaga dan memberi nafkah ahli keluarganya.

Apabila ditegaskan di dalam al-Qur'an bahawa lelaki, sebagai kelompok manusia dan bukan orang perorangan,

50 Yang dimaksudkan di sini bukan lelaki lebih cerdas daripada perempuan, tetapi kemampuan mereka secara umum berbeza, di mana lelaki 'lebih' mampu menggunakan akalnya melebihi perasaannya, dan 'lebih' mampu untuk berfikir hal-hal yang umum (kullī) berbanding hal-hal yang khusus $(j u z ' \bar{\imath})$.

${ }^{51}$ Lihat Fakhr al-Dīn al-Rāzi. Mafātīh al-Ghayb, tafsir surah al-Nisā', 34.

52 Antara lain hadith nabi yang bermaksud: "Apabila seorang wanita itu menunaikan solat lima waktu, berpuasa pada bulan Ramadan, menjaga kemaluannya, mentaati suaminya, dikatakan padanya "masuklah ke Syurga melalui pintu mana yang ia suka". Hadith riwayat Aḥmad dan Ibn Hibbān, no. 4163. Begitu juga hadith "Jika ada aku menyuruh seseorang untuk sujud kepada orang lain nescaya aku akan menyuruh seorang wanita untuk sujud kepada suaminya”. Hadith riwayat al-Tirmidhi, no. 1159; Ibn Majah no. 1853. Dalam riwayat Ibn Mājah terdapat tambahan: "Demi Allah yang jiwa Muhammad berada di tanganNya tidaklah seorang wanita itu menunaikan hak Tuhannya sehingga ia menunaikan hak suaminya.." 
adalah pemimpin (qawwāmūn) bagi kaum wanita, ${ }^{53}$ dan diberikan kelebihan satu darjat berbanding perempuan, ini bermakna bukan semua lelaki dapat menjadi pemimpin kepada kaum wanita dalam semua bidang. Boleh jadi dalam bidang-bidang tertentu terdapat individu wanita yang mempunyai kemampuan melebihi ramai lelaki, namun dengan kelebihan yang Allah berikan kepada umumnya kaum lelaki, mereka sewajarnya mampu dan mesti mampu menjadi pemimpin kepada kaum wanita. Maka kepimpinan lelaki ke atas wanita (al-qiwāmah) bukan suatu bentuk superiority (keunggulan), memiliki martabat yang lebih tinggi, yang memberi isyarat bahawa wanita adalah inferior iaitu memiliki martabat yang lebih rendah.

Justeru, kepimpinan yang dimaksudkan bukanlah suatu kemuliaan, bahkan kepimpinan dalam Islam pada umumnya bukanlah suatu kemuliaan dan kebanggaan. Ia adalah suatu beban yang berat kerana pemimpin perlu berkhidmat untuk yang dipimpin. Dengan kata lain, penegasan bahawa kaum lelaki adalah pemimpin kepada kaum wanita tidak bermakna bahawa kaum lelaki mendapat kedudukan yang mulia dan istimewa manakala kaum wanita mendapat kedudukan yang hina. Ia juga tidak bermakna bahawa kaum lelaki adalah tuan dan kaum wanita adalah hamba, kerana perkahwinan bukan perhambaan. Meskipun kepimpinan yang dimaksudkan di atas menuntut ketaatan pihak isteri, namun ia bukan ketaatan yang mutlak. Ia adalah ketaatan yang bersyarat, iaitu selama mana perintahnya itu tidak melanggar perintah Allah dan RasulNya.

Jika dilihat dari perspektif sekular dan liberal, apapun bentuk perbezaan dalam peranan dan pembahagian tugas yang berbeza adalah suatu bentuk diskriminasi dan mencerminkan budaya patriarki. Oleh kerana Islam menekankan kepentingan institusi keluarga agar harmoni

${ }^{53}$ Surah al-Nisā': 34. 
dan sejahtera maka perbezaan peranan ini amat perlu untuk memastikan kelestarian hubungan keluarga.

Ketika seorang lelaki masuk ke alam rumahtangga maka ia dihadapkan dengan suatu 'aqad, yakni kontrak, dan melalui kontrak ini seorang lelaki bersetuju menerima seorang wanita untuk menjadi isterinya serta bertanggungjawab untuk memberi nafkah kepadanya. Ia secara tidak langsung bersetuju untuk memegang amanah sebagai kepala rumahtangga. Kegagalannya untuk memperlakukan isterinya dengan baik boleh membatalkan kontrak ini, dan oleh kerananya seorang hakim boleh menjatuhkan hukum fasakh. ${ }^{54}$ Demikian juga wanita yang secara suka rela melakukan 'aqad nikah, secara tidak langsung sebenarnya telah bersetuju untuk menerima kepimpinan lelaki yang menjadi suaminya, bersetuju untuk mentaatinya selama mana ia adalah perkara yang baik dan tidak bercanggah dengan kehendak Allah dan Rasul.

Apabila peranan masing-masing dilihat sebagai suatu amanah maka seorang lelaki-pemimpin akan berusaha untuk memberi yang terbaik kepada ahli keluarganya. Telah menjadi aturan hidup di dunia ini bahawa semakin banyak kita memberi, semakin banyak kita dapat. Manusia yang bersyukur setelah menerima sesuatu kebaikan sewajarnya ia akan membalas budi baik itu dengan memberi lebih. Apabila seorang suami itu adalah orang yang bertanggungjawab, ia akan berusaha untuk kebahagiaan dan kesejahteraan isteri dan keluarganya.

Sebagai timbal balik maka sewajarnya isteri akan membalas budi dengan melakukan yang terbaik untuk kebahagiaan suami. Seorang isteri yang berterima kasih kepada suaminya akan memastikan suami diberikan layanan yang istimewa, memasak makanan yang digemari

\footnotetext{
${ }^{54}$ Kerana itu seorang isteri berhak untuk menuntut cerai di mahkamah apabila lelaki gagal melaksanakan tugasnya dengan baik atau mencederakannya. Fasakh bermaksud melepaskan ikatan perkahwinan.
} 
suami, mengurus rumahtangga dengan baik, semua dilakukan dengan rela hati, bukan terpaksa. Adanya kerelaan dalam diri seorang wanita dan ketulusan hati dalam melaksanakan tanggungjawabnya ini menunjukkan bahawa ia bukanlah patriarki jauh sekali penghambaan terhadap kaum wanita. Ia hanya menjadi suatu bentuk penindasan apabila isteri dipaksa berbuat demikian walhal suami tidak melaksanakan tanggungjawabnya.

Maka di sini apa yang penting ditekankan adalah agar setiap pihak melaksanakan tanggungjawab dan kewajipan masing-masing sebagaimana dituntut oleh agama, agar kepentingan dan hak kedua belah pihak, suami dan isteri, terpelihara. Untuk memastikan hal ini maka perlu ada langkah penjagaan, iaitu pendidikan. Melalui pendidikan akan muncul kesedaran dalam diri setiap orang untuk menjadi seorang Muslim, suami dan isteri yang baik, sentiasa menjaga dan menunaikan tanggungjawabnya kepada Allah, agama, keluarga dan masyarakat. Kurangnya pendidikan menyebabkan kerosakan dan kezaliman rumahtangga.

\section{Konsep Keadilan dan Kesamarataan (Equality)}

Allah SWT menciptakan setiap sesuatu berbeza dari yang lain, dan ini merupakan suatu tanda kebesaranNya. Umum mengetahui bahawa manusia diberikan kelebihan berbanding makhluk yang lain. Ibn Khaldūn menegaskan bahawa meskipun dari segi kekuatan fizikal, binatang memiliki kelebihan berbanding manusia, namun dengan kurniaan akal iaitu kelebihan yang paling tinggi diberikan kepada makhluk, maka manusia boleh menguasai makhluk yang lain dan mengatur kehidupan di muka bumi sehingga mampu membangun peradaban. ${ }^{55}$

Hanya Iblis yang menafikan kelebihan yang diberikan kepada Adam oleh Allah SWT. Ia tetap dengan

55 Ibn Khaldūn, Muqaddimah Ibn Khaldūn (Beirut:Dār al-Fikr, 2004), 53. 
pendiriannya bahawa dirinya lebih baik daripada Adam kerana diciptakan daripada api. Penafian ini diiringi dengan keengganan mengikut perintah Allah, ketika Iblis diperintahkan untuk sujud kepada Adam a.s., ia enggan kerana tidak melihat adanya kelebihan yang diberikan kepada Adam. Hakikat bahawa Adam memiliki kelebihan berbanding Iblis, dan semua makhluk ciptaan Allah, sehingga melayakkan dirinya diberi penghormatan sujud oleh Malaikat dan Iblis diterangkan di dalam al-Qur'an. ${ }^{56}$

Di sini tidak timbul persoalan bahawa Iblis telah diperlakukan tidak adil oleh Allah, kerana tiada sesiapa yang dapat mempersoalkan mengapa Allah memberi kelebihan kepada sesetengah makhlukNya berbanding yang lain. Ia sama sahaja dengan mempersoalkan kebijaksanaan dan keadilan Allah SWT, sedangkan manusia tidak mengetahui perancangan-Nya. Kelebihan yang diberikan kepada Adam ini meletakkan manusia di atas makhluk-makhluk yang lain, sebagai khalifah di muka bumi, dan melayakkannya untuk mengurus segala sumber yang ada di bumi dan di langit untuk tujuan yang diridhai oleh Allah. ${ }^{57}$ Dari sini dapat disimpulkan bahawa kelebihan yang dimiliki oleh Adam, dan kedudukan yang tinggi diberikan kepadanya berbanding makhluk yang lain, memberi isyarat yang jelas bahawa tiada kesamarataan (equality) antara makhluk-makhluk Allah tersebut.

Hakikatnya setiap manusia memiliki personaliti dan keunikan yang tersendiri. Meskipun wujud persamaan tetapi perbezaan itulah yang menjadikan setiap satunya unik dan bernilai. Ketentuan Allah memberi kelebihan kepada sesetengah manusia berbanding yang lain, serta mengangkat sebahagian ke atas sebahagian yang lain merupakan suatu kebijaksanaanNya. ${ }^{58}$ Dengan adanya

\footnotetext{
${ }^{56}$ Surah al-Baqarah: 30-31.

${ }^{57}$ Surah Luqmān: 20; al-Jāthiyah:12.

58 Surah al-An'ām: 165: "Dan Dia lah yang menjadikan kamu khalifah di bumi dan meninggikan setengah kamu atas setengahnya yang lain
} 
tingkatan-tingkatan ini maka peradaban manusia dapat dibangunkan, berbanding apabila semua manusia diberikan kelebihan yang sama maka akan berlaku kekacauan dan keengganan untuk tunduk dan patuh kepada orang lain yang diberikan kelebihan. Kelebihan yang diberikan kepada seseorang individu adalah suatu ujian daripada Allah, yang akan dipertanggungjawabkan kelak di akhirat.

Perbezaan antara mnausia, oleh kerana itu, perlu dilihat secara positif. Mengambil kira perbezaan inilah maka kaum ibu sewajarnya mendapat layanan yang istimewa oleh anak-anaknya. Dalam suatu hadith disebutkan bahawa orang yang paling patut disantuni adalah "ibumu" disebut oleh Rasulullah tiga kali, barulah kemudian "bapamu". ${ }^{59}$ Perbezaan layanan ini adalah sesuatu yang wajar melihat kepada besarnya pengorbanan seorang ibu dalam kehidupan anaknya. Seorang anak akan sangat terhutang budi kepada ibunya, kerana pengorbanan yang dilakukan oleh ibu seperti melahirkan dan menyusukan, sehingga meskipun bapa juga banyak berkorban tetapi pengorbanan ibu jauh lebih besar. Jika perbezaan antara ibu dan bapa yang sah tidak diambil kira maka tiada layanan istimewa diberikan kepada kaum ibu, dan pengorbanan ibu yang besar itu tadi akan terlihat tidak dihargai sewajarnya. Justeru itu layanan sama rata kepada kedua ibu dan bapa, adalah satu bentuk ketidakadilan.

Oleh kerana itu layanan berbeza perlu dilakukan kepada dua orang manusia yang memiliki perbezaan yang sah. Justeru, ia tidak wajar dianggap sebagai suatu bentuk diskriminasi. Sebaliknya layanan berbeza kepada dua orang

beberapa darjat, kerana Ia hendak menguji kamu pada apa yang telah dikurniakanNya kepada kamu. Sesungguhnya Tuhanmu amatlah cepat azab seksaNya, dan sesungguhnya Ia Maha Pengampun, lagi Maha Mengasihani”.

${ }^{59}$ Hadith riwayat Muslim, no. 4621, al-Bukhāri, no. 5626. Lihat juga hadith yang diriwayatkan oleh Aḥmad, al-Nasā'i dan Ibn Mājah yang menyatakan bahawa Syurga berada di bawah telapak kaki ibu (Sunan Ibn Mājah bi Sharh al-Sindī, 180). 
yang tidak berbeza serta tidak memiliki perbezaan yang sah, adalah suatu diskriminasi. Sebagai contoh meskipun seorang khalifah adalah pemimpin masyarakat yang patut mendapat penghormatan dan layanan yang berbeza, namun di mahkamah dan di sisi undang-undang, ia tidak boleh diberikan layanan berbeza dengan yang diberikan kepada orang biasa. Di sisi hukum, keduanya tidak lagi dilihat sebagai pemimpin ataupun rakyat, miskin ataupun kaya, kuat ataupun lemah, tetapi sebagai manusia yang tertakluk kepada undang-undang, sebagai warganegara yang wajib mematuhi undang-undang. ${ }^{60}$ Di sini kelebihan yang ada pada khalifah tidak boleh diambilkira meskipun di tempat lain, dalam situasi yang berbeza, ia perlu ditaati dan ini merupakan perbezaan yang sah.

Konsep kesetaraan (musāwāh atau equality) yang dicanangkan oleh sebahagian pemikir Barat bertujuan untuk menghilangkan perbezaan di atas. Konsep equality berasal dari bahasa Perancis, égalité, kemudian menjadi egalitarianism atau equalitarianism dan menjadi tunjang bagi liberalisme pada zaman moden di Barat. Konsep equality jarang digunakan pada masa lalu. Ia hanya popular dan menyebar luas setelah revolusi Perancis. Konsep yang banyak dibahas oleh para sarjana, termasuk ahli falsafah Yunani seperti Aristotle ${ }^{61}$ begitu juga al-

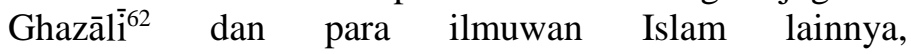
adalah justice atau dalam bahasa Arab al- 'adl (keadilan), yang bermaksud meletakkan sesuatu pada tempatnya.

${ }^{60}$ Terdapat kisah yang diriwayatkan oleh al-Bayhaqi tentang keadilan Shurayh al-Qāḍi ketika menyelesaikan kes Sayyidina 'Ali, khalifah umat Islam ketika itu menentang seorang Nasrani atas kepemilikan baju besi. Kegagalan Sayyidina 'Ali mendatangkan saksi menyebabkan kes itu dimenangi oleh Nasrani, meskipun sebenarnya baju besi itu milik beliau.

${ }^{61}$ Aristotle, Nicomachean Ethics (New York: Prometheus Books, 1987), 165.

${ }^{62}$ Al-Ghazālì, Mīzān al- ‘Amal (Kaherah: Dār al-Ma‘ārif, 1961), 273. 
Ini kerana, setiap sesuatu ada tempatnya masingmasing yang sesuai baginya dan tidak sesuai bagi yang lain. Equality atau kesetaraan membawa maksud kesamaan (sameness), mengisyaratkan penyamarataan (levelling), dan jika diletakkan bergandingan dengan gender maka yang berlaku adalah penyamarataan lelaki dengan perempuan. Maka equality cuba menyamaratakan sesuatu yang Allah ciptakan berbeza dan bertingkat. Di dalam alQur'an telah dijelaskan bahawa Allah memberikan kelebihan bagi kaum lelaki satu darjat berbanding perempuan. Dalam surah al-Baqarah, ayat 228, Allah berfirman yang bermaksud:

"Dan isteri-isteri itu mempunyai hak yang sama seperti kewajipan yang ditanggung oleh mereka (terhadap suami) dengan cara yang sepatutnya; dalam pada itu lelaki (suami-suami itu) mempunyai satu darjat kelebihan atas orangorang perempuan (isterinya). Dan (ingatlah), Allah Maha Kuasa, lagi Maha Bijaksana."

Para Mufassirūn menegaskan bahawa meskipun lelaki diberikan kelebihan satu darjat di atas wanita namun kaum wanita mempunyai hak sebagaimana mereka memikul kewajipan. Al-Qurțūbi mengatakan bahawa isteri mempunyai hak untuk dilayani dengan baik, dan diperlakukan dengan terhormat oleh suami mereka, sebagaimana mereka diwajibkan untuk mentaati suami. ${ }^{63}$ Perkataan darajah menurutnya lagi bermaksud kedudukan yang lebih di atas kemampuannya untuk berinfaq, membayar diyat, harta waris dan jihad ${ }^{64}$. Dengan kata lain lelaki diberikan kelebihan memimpin rumah tangga kerana tanggungjawab mereka lebih dalam memberi nafkah dan bekerja.

63 Al-Qurțūbì, al-Jāmi ‘ li Aḥkām al-Qur'ān (Beirut: Mu'assasat alRisālah, 2006), 4: 52.

${ }^{64}$ Ibid. 
Dengan kelebihan ini maka lelaki sebagai kepala rumahtangga perlu ditaati dalam perkara yang ma'ruf (baik). Demikian juga perempuan mempunyai hak untuk dikasihi, disantuni, dihormati, dijaga dan dipelihara apabila perempuan menunaikan tanggungjawabnya sebagai isteri dan ibu yang membesarkan dan mengasuh anak-anak. Dengan wujudnya persefahaman dan kerjasama, setiap pihak yang jelas tentang kedudukan masing-masing dan tahu kewajipan dan hak masing-masing maka sudah tentu natijah yang muncul adalah keharmonian dan keadilan dalam rumah tangga dan masyarakat.

Maka pernyataan bahawa kaum lelaki diberikan satu darjat kelebihan ke atas kaum perempuan bukanlah suatu bentuk diskriminasi. Ia adalah suatu bentuk penegasan tentang letak lelaki (suami) dan letak perempuan (isteri) dalam institusi keluarga. Ayat ini perlu dibaca dengan ayat sebelum ini yang menyatakan bahawa kaum lelaki adalah pemimpin kepada kaum wanita. ${ }^{65}$ Justeru dalam ayat ini sebelum Allah menegaskan kelebihan darjat yang diberikan kepada suami, Allah SWT telah terlebih dahulu menjelaskan kewajipan suami menunaikan hak-hak isterinya seimbang dengan kewajipan dan tanggungjawab isteri kepada suami.

Di zaman Rasulullah SAW terdapat seorang wanita yang mengadu kepada Baginda akan rasa kurang puas hati sesetengah wanita terhadap kelebihan yang diberikan kepada kaum lelaki. ${ }^{66}$ Maka turun ayat yang menegur sikap seperti ini, yang maksudnya:

65 Surah al-Nisā', ayat 34: "Kaum lelaki itu adalah pemimpin dan pengawal yang bertanggungjawab terhadap kaum perempuan, oleh kerana Allah telah melebihkan orang-orang lelaki (dengan beberapa keistimewaan) atas orang-orang perempuan, dan juga kerana orangorang lelaki telah membelanjakan (memberi nafkah) sebahagian dari harta mereka. Maka perempuan-perempuan yang soleh itu ialah yang taat (kepada Allah dan suaminya)."

${ }^{66}$ Lihat Tafsir Fakhr al-Dìn al-Rāzì bagi ayat 32 surah al-Nisā'. 
"Dan janganlah kamu terlalu mengharapkan (ingin mendapat) limpah kurnia yang Allah telah berikan kepada sebahagian dari kamu (untuk menjadikan mereka) melebihi sebahagian yang lain. (Kerana telah tetap) orang-orang lelaki ada bahagian dari apa yang mereka usahakan, dan orang-orang perempuan pula ada bahagian dari apa yang mereka usahakan; (maka berusahalah kamu) dan pohonkanlah kepada Allah akan limpah kurniaNya. Sesungguhnya Allah sentiasa Mengetahui akan tiap-tiap sesuatu" ${ }^{67}$

Allah SWT menciptakan manusia tidak sama, masingmasing memiliki kelebihan di atas yang lain, dan setiap orang perlu diletakkan berdasarkan tingkat masing-masing. Meletakkan setiap orang pada tempatnya yang berbeza itu adalah keadilan, sedangkan tindakan menyamaratakan mereka semua adalah ketidakadilan.

\section{Kesimpulan}

Daripada perbincangan di atas jelas bahawa konsep kesetaraan gender yang diutarakan oleh kaum feminis telah mengetepikan hakikat bahawa fitrah lelaki dan perempuan berbeza. Perbezaan peranan dan tanggungjawab antara dua gender ini oleh kaum feminis telah dianggap sebagai ketidaksamaratan (inequality) dan ketidaksamarataan dianggap sama dengan ketidakadilan (injustice). Kesalahan besar kaum feminis adalah menganggap bahawa perbezaan lelaki dan perempuan yang ditetapkan oleh Islam adalah suatu bentuk patriarki: 'hanya apabila sesuatu agama itu memberikan kesamarataan maka barulah agama itu tidak lagi dianggap mengamalkan patriarki.'

Di sinilah letak kekeliruan yang besar. Adanya perbezaan tidak bermakna ianya suatu ketidakadilan, kerana keadilan tidak boleh disamakan dengan

${ }^{67}$ Surah al-Nisā': 32. 
kesamarataan, justeru penyamarataan sesuatu yang berbeza adalah suatu ketidakadilan. Wujudnya perbezaan peranan antara lelaki dan perempuan juga tidak boleh ditafsirkan sebagai penindasan, justeru ia sesuai dengan faham keadilan, iaitu meletakkan sesuatu pada tempatnya.

Para ulama' yang mentafsirkan al-Qur'an menetapkan apa yang ditetapkan oleh Allah dan Rasul, iaitu meletakkan lelaki dan wanita di tempat mereka masing-masing sesuai dengan fitrah. Mereka tidak melakukannya berdasarkan kepentingan kaum lelaki serta tidak mendikskriminasikan kaum wanita serta berlaku berat sebelah terhadap mereka. Para ulama' pada dasarnya mengikut kaedah yang disepakati dalam ilmu tafsir, dan tidak mentafsirkan alQur'an dengan sewenang-wenang. Dengan pemahaman yang tepat terhadap tafsiran al-Qur'an oleh para ulama' Ahl al-Sunnah wa al-Jamā'ah, dan bukan tafsiran sempit golongan Pseudo-Salafi, kita mendapati bahawa perempuan dalam Islam tidak ditindas, justeru martabat serta kemuliaan wanita tetap dijaga sebagaimana terbukti dalam sejarah Islam.

Perbezaan peranan dan fungsi antara lelaki dan perempuan perlu dilihat sebagai sesuatu yang positif. Justeru dengan adanya perbezaan maka suami dan isteri dapat berkerjasama, boleh saling melengkapi dan hidup bersama. Mereka hanya perlu kedewasaan dan kebijaksanaan dalam menangani perbezaan. Sebaliknya jika keduanya memiliki sifat dan keupayaan yang sama maka kerjasama tidak akan memberi apa-apa nilai tambah, tiada daya tarik antara satu sama lain, dan tidak akan berlaku saling melengkapi. Tiada kekurangan yang boleh dipenuhi oleh pasangannya, dan tiada keperluan untuk mereka hidup bersama.

Meskipun terdapat pelbagai bentuk feminisme, namun pada hakikatnya wacana feminisme, baik di Barat mahupun di dunia Islam, adalah bertolak belakang dengan agama, bahkan ada yang anti-agama ataupun sekurang-kurangnya 
berusaha untuk mentafsirkan semula agama agar bersesuaian dengan ideologi feminisme.

Pandangan negatif Barat terhadap kedudukan wanita adalah bernuansa kolonialisme dan projek pembebasan wanita yang dilaungkan sejak awal abad ke-20 pada hakikatnya juga adalah untuk kepentingan penjajah. Kerana itu jelas bagi kita bahawa konsep kesetaraan gender ( gender equality) tidak relevan bagi umat Islam. Selain kerana ianya menyalahi aturan dan kehendak Tuhan, iaitu fitrah dan tabiat yang telah Ia tetapkan, juga kerana feminisme muncul di Barat akibat daripada penindasan terhadap kaum wanita. Feminisme di Barat pada dasarnya adalah pemberontakan dan kemarahan terhadap ketidakadilan dan kemarahan yang disalurkan secara halus. Ia adalah perlawanan secara senyap, khususnya melalui penulisan kemudian persatuan-persatuan, terhadap budaya masyarakat yang dikatakan patriarki.

Oleh kerana pelaku ketidakadilan ini adalah lelaki, maka lelaki yang menjadi tempat kemarahan itu. Di sinilah letak kesilapannya, sepatutnya masalah ini tidak dilihat tertumpu pada gender tetapi masalah berleluasanya ketidakadilan, masalah sosial dan masalah keruntuhan nilai kemanusiaan, yang berakar pada persoalan metafizik dan pandangan alam. Kesilapan tumpuan ini diakui oleh Doris Lessing (1919-2013), seorang tokoh feminis yang telah melepaskan diri daripada feminisme dan mendapat anugerah Nobel pada tahun 2007, sebagaimana dilaporkan oleh majalah Guardian, Lessing mengatakan ${ }^{68}$ :

"I find myself increasingly shocked at the unthinking and automatic rubbishing of men which is now so part of our culture that it is hardly even noticed".

68 The Guardian, "Lay off men, Lessing Tells Feminists," https://www.theguardian.com/uk/2001/aug/14/edinburghfestival2001 .edinburghbookfestival2001. 
Menurut Lessing peperangan lawan jenis (sex war) yang dilancarkan oleh golongan feminis di Barat sejak abad ke-19 ternyata telah memunculkan suatu budaya di Barat yang juga negatif dan kontra produktif iaitu budaya yang merendahkan kaum lelaki.

\section{Rujukan}

Ahmed, K. ed. The Position of Woman in Islam. Safat: Islamic Book Publishers, 1993.

Al-Albānī, Nāṣir al-Dīn. Jilbāb al-Mar'ah al-Muslimah fī al-Kitāb wa al-Sunnah. Beirut: Dar al-Salam. 2002.

Amin, Qāsim. Taḥrīr al-Mar'ah. Kaherah: Nawabigh alFikr, t.t.

Aristotle. Politics, terj. Ernest Barker. Oxford: Clarendon Press, 1948.

Aristotle. Nicomachean Ethics. New York: Prometheus Books, 1987.

Al-Asfahani, al-Rāghib. Mufradāt Alfāz al-Qur'ān. Damshiq: Dār al-Qalam, 2011.

Al-'Asqalani, Ibn Hajar. Fath al-Bārī. Riyadh: Dār alSalām, t.t.

Al-'Asqalanī, Ibn Hajar. Al-Ișābah fi Tamyīz al-Ṣahābah. Beirut: Dar al-Kutub al-'Ilmiyyah, 1995.

Astell, Mary. Political Writings, ed. Patricia Springborg. Cambridge: Cambridge University Press, 1996.

Al-Attas, S.M.N. Prolegomena to the Metaphysics of Islam. Kuala Lumpur: ISTAC, 1995.

Al-Attas, S.M.N. Islam and Secularism. Kuala Lumpur: ISTAC, 1993.

Baring, Evelyn. Modern Egypt. London: Macmillan, 1908. Barlas, A. Believing Women in Islam: Unreading Patriarchal Interpretations of the Qur'an. Austin: University of Texas Press, 2002.

Beauvoir, Simone de. The Second Sex. New York: Vintage Books, 2011.

Bullock, Katherine. Rethinking Muslim Woman and the Veil. Virginia: IIIT, 2010. 
Al-Ghazālì, Abū Hāmid. Mīzān al- 'Amal (Kaherah: Dār alMa ārif, 1961.

Al-Ghazālì, Abū Hāmid. "Iljām al-'Awām 'an 'Ilm alKalām.” Dalam Majmū 'at Rasā'il al-Imām al-Ghazālì. Kaherah: Maktabah al-Tawfiqiyyah, t.t.

Ibn Bāz. Risālah Tabhath fī Masā'il al-Hijāb wa al-Sufür. Madinah: al-Jāmi'ah a-Islāmiyyah, t.t.

Ibn Khaldūn. Muqaddimah Ibn Khaldūn (Beirut: Dār alFikr, 2004.

Ibn Taymiyyah. Hijāb al-Mar'ah wa Libāsuhā fi al-Salāh. Riyadh: Maktabah al-Ma'ārif, 2005.

Al-Jurjānī. Kitāb al-Ta'rīfât, ed. Muḥammad Șiddīi alMinshāwì. Kaherah: Dār al-Faḍilah, t.t.

Al-Maqrizī, Aḥmad bin 'Alì. Imtā' al-Asmā'. Beirut: Dar al-Kutub al-'Ilmiyyah, 1999.

Lombard, Denys. Kerajaan Aceh. Jakarta: KPG, Ecole francaise d'Extreme-Orient, 2008.

Mernissi, Fatima. "Virginity and Patriarchy." In Women and Islam, ed. al-Hibri, A. Oxford: Pergamon Press, 1982.

Mernissi, Fatima. Beyond the Veil. London: Al Saqi Books, 1985.

Mernissi, Fatima. The Veil and the Male Elite: A Feminist Interpretation of Women's Rights in Islam. New York: Basic Book, 1991.

Mir-Hosseini, Ziba. Islam and Gender: The Religious Debate in Contemporary Iran. New York: Princeton University Press, 1999.

Muhsin, A. Wadud. Qur'an and Women. Kuala Lumpur: Penerbit Fajar Bakti, 1992.

Al-Nawawì. Sharh Ṣaḥ̄h Muslim. Beirut: Dār al-Ma'rifah, 1998.

Al-Qurțūbì. Al-Jāmi' li Aḥkām al-Qur'ān. Beirut: Mu'assasat al-Risālah, 2006.

Rahman, Fazlur. Major Themes of the Qur'an. Minneapolis: Bibliotheca Islamica, 1980. 
Al-Rāzì, Fakhr al-Dīn. Mafātīh al-Ghayb. Beirut: Dār alKutub al-'Ilmiyyah, 2009.

Șāliḥ bin 'Uthaymin. Risālah al-Hijāb. Madinah: alJāmi'ah a-Islāmiyyah, t.t.

Sartre, Jean-Paul. Existentialism and Humanism, terj. Philip Mairet. London: Methuen, 1948.

Spellman, W. M. A Short History of Western Political Thought. London: Palgrave-Macmillan, 2011.

Stone, Alison. An Introduction to Feminist Philosophy. Cambridge: Polity Press, 2007.

The Guardian, "Lay off men, Lessing Tells Feminists," https://www.theguardian.com/uk/2001/aug/14/edinburg hfestival2001.edinburghbookfestival2001.

Wadud, Amina. Inside the Gender Jihad. Oxford: Oneworld Publication, 2006.

Wadud, Amina. Qur'an and Woman. Kuala Lumpur: Fajar Bakti, 1992.

Wan Mohd Nor Wan Daud. Islamization of Contemporary Knowledge and the Role of the University in the Context of De-Westernization and Decolonization. Johor Bahru: Penerbit Universiti Teknologi Malaysia, 2013.

Wollstonecraft, Mary. A Vindication of the Rights of Woman. Dublin: J. Stockdale, 2010.

Al-Zabīīi, Muhammad Murtậā. Tāj al- 'Arūs. Beirut: Dār Sadir, 2011.

Zainah Anwar, ed. Wanted: Equality and Justice in Muslim Family. Petaling Jaya: Musawah Sisters in Islam, 2009. Al-Zamakhshari, Muhammad bin 'Umar. Asās alBalāghah. Beirut: Dār al-Kutub al-'Ilmiyyah, 1998. 
Khalif Muaamar \& Adibah, "Konsep Kesetaraan Gender Menurut Perspektif Islam \& Barat," Afkār Vol. 21 Issue 2 (2019): 33-74 